\title{
Ecotype and Foliar Fertilization with Florovit Affect Herbage Yield and Quality of Greenhouse-Grown Basil (Ocimum basilicum L.)
}

\author{
Joanna Majkowska-Gadomska ${ }^{1}$, Emilia Mikulewicz ${ }^{1}$, Artur Dobrowolski ${ }^{1} \&$ Anna Dziedzic $^{1}$ \\ ${ }^{1}$ Department of Horticulture, Faculty of Environmental Management and Agriculture, University of Warmia and \\ Mazury in Olsztyn, Olsztyn, Poland \\ Correspondence: Joanna Majkowska-Gadomska, Department of Horticulture, University of Warmia and Mazury \\ in Olsztyn, Prawocheńskiego 21, 10-957 Olsztyn, Poland. E-mail: majkowska-gadomska@uwm.edu.pl
}

Received: January 6, 2015 Accepted: February 9, 2015 Online Published: March 15, 2015

doi:10.5539/jas.v7n4p195 URL: http://dx.doi.org/10.5539/jas.v7n4p195

\begin{abstract}
Basil is usually grown in $0.5-0.7 \mathrm{dm}^{3}$ pots, at 25 plants per pot. However, potted basil plants wilt and die easily due to high plant density, low substrate volume, insufficient moisture and nutrient depletion. The aim of this study was to determine the herbage yield and nutritional value of greenhouse-grown basil. A two-factorial experiment was performed in a randomized block design with three replications, in 2012-2013. A two-factorial experiment was performed in a randomized block design with three replications, in 2012-2013 Six basil (Ocimum basilicum L.) ecotypes were analyzed: sweet basil, 'Queen of Siam' basil, purple basil, cinnamon basil, lemon basil and 'Minette' basil. The second experimental factor was foliar fertilization with Florovit at a concentration of $0.5 \%$ and $1 \%$. Basil yield was significantly affected by the ecotype and the interaction between the experimental factors. 'Minette' basil fertilized with $1 \%$ Florovit solution was characterized by the highest fresh herbage yield. A statistical analysis revealed that Florovit had no significant effect on basil yield. The concentrations of dry matter, total sugars, L-ascorbic acid and nitrates $(\mathrm{V})$ in basil herbage varied across ecotypes. Foliar fertilization had a significant effect on the organic acid content of basil leaves. The accumulation of the analyzed components in basil herbage was significantly affected by the interaction between the experimental factors. Basil yield was significantly affected by the ecotype. 'Minette' and 'Siam Queen' basil was characterized by the highest fresh herbage yield. The fresh herbage of 'Minette' basil contained the lowest concentrations of dry matter, total sugars, L-ascorbic acid, organic acids and nitrates(V).
\end{abstract}

Keywords: basil, yield, component, quality, nitrates(V)

\section{Introduction}

Basil is a popular culinary herb that can be grown in pots and containers Fresh potted basil available on the market is characterized by extended post-harvest shelf-life and quality. Greenhouse production ensures a year-round supply of fresh herbs, spices and seasonings (Aharoni et al., 1993; Jadczak et al., 2006; Biesiada \& Kus, 2010). Due to regular control and monitoring of the greenhouse environment, plants grown under cover accumulate lower amounts of undesirable compounds such as nitrates(III), nitrates (V) and heavy metals (Wierzchowska-Renke et al., 1995).

Basil is usually grown in $0.5-0.7 \mathrm{dm}^{3}$ pots, at 25 plants per pot. However, potted basil plants wilt and die easily due to high plant density, low substrate volume, insufficient moisture and nutrient depletion. In view of the above, research was undertaken to improve greenhouse basil production conditions. Six basil ecotypes were compared in the study. Basil plants were grown in $3.0 \mathrm{dm}^{3}$ containers to ensure adequate substrate solution volume. Another important consideration in greenhouse production is the appropriate use of fertilizers to maximize the yield and improve the biological value of potted herb plants. However, fertilizer rates are usually calculated for basil grown in the field (Nurzynska-Wierdak, 2012). Most research studies conducted to date have investigated simple fertilizers, including foliar application of $0.5 \%$ urea solution (Nurzynska-Wierdak \& Borowski, 2011), fertigation with the use of ammonium nitrate and potassium sulfate (Nurzyńska-Wierdak et al., 2012), and the application of calcium carbonate to neutralize soil acidity (Dzida, 2010a).

The objective of this study was to determine the herbage yield and nutritional value of greenhouse-grown basil fertilized with the compound fertilizer Florovit. 


\section{Method}

A two-factorial experiment was performed in a randomized block design with three replications, in 2012-2013, in a greenhouse in the Experimental Garden of the University of Warmia and Mazury in Olsztyn. The first experimental factor were six basil (Ocimum basilicum L.) ecotypes: sweet basil, 'Queen of Siam' basil, purple basil, cinnamon basil, lemon basil and 'Minette' basil. The second experimental factor was foliar fertilization with Florovit at a concentration of $0.5 \%$ and $1 \%$. Florovit is a liquid compound fertilizer that can be applied to plant foliage and soil. It has a $\mathrm{pH}$ of 3.3-4.3, and contains $\mathrm{N}: \mathrm{P}: \mathrm{K}(3.0: 0.0: 2.0)$, copper $\left(70 \mathrm{mg} \mathrm{dm}^{-3}\right)$, iron $\left(400 \mathrm{mg} \mathrm{dm}^{-3}\right)$, manganese $\left(170 \mathrm{mg} \mathrm{dm}^{-3}\right)$, molybdenum $\left(20 \mathrm{mg} \mathrm{dm}^{-3}\right)$, zinc $\left(150 \mathrm{mg} \mathrm{dm}^{-3}\right)$, calcium, magnesium, sulfur and film-forming agents (inco.pl leaflet).

Basil plants were grown in $3.0 \mathrm{dm}^{3}$ containers placed on movable flood tables. Experimental unit area was $1 \mathrm{~m}^{2}$, and each replicate consisted of 25 pots. Each year, in mid-February, basil seeds were sown in containers (four seeds per container) filled with organic substrate with a $\mathrm{pH}\left(\mathrm{H}_{2} \mathrm{O}\right)$ of 6.7 , salt concentration of $0.23 \mathrm{~g} \mathrm{~kg}^{-1}$ and the following chemical composition: $\mathrm{N}-\mathrm{NH}_{4}-25 \mathrm{mg} \mathrm{dm}^{-3}, \mathrm{~N}^{-\mathrm{NO}_{3}}-10 \mathrm{mg} \mathrm{dm}^{-3}, \mathrm{P}-41 \mathrm{mg} \mathrm{dm}{ }^{-3}, \mathrm{~K}-129 \mathrm{mg} \mathrm{dm}^{-3}$, $\mathrm{Ca}-1050 \mathrm{mg} \mathrm{dm}^{-3}, \mathrm{Mg}-87 \mathrm{mg} \mathrm{dm}^{-3}$. The recommended cultivation practices for basil were applied during the growing season. Fertilization began two weeks after seedling emergence, and it was continued throughout the growing season at 14-day intervals. Basil leaves were harvested at the beginning of flowering. The plants were cut manually, $5 \mathrm{~cm}$ above the ground. The chemical composition of basil herbage was determined at harvest. Average samples of basil herbage were collected from the marketable yield in each treatment, according to Polish Standard PN-72/A-75050. The samples were analyzed in the laboratory of the Department of Horticulture, University of Warmia and Mazury in Olsztyn to determine the content of:

$>$ Dry matter - by drying the plant material at $105^{\circ} \mathrm{C}$ to constant weight (PN-90/A-75101/03);

$>$ Total sugars - by the Luff-Schoorl method (PN-90/A-75101/07);

$>\quad$ L-ascorbic acid - by the Tillmans method modified by Pijanowski (PN-90/A-75101/11);

> Organic acids expressed as malic acid equivalents - by titration, as described by Pietersburgski;

B-carotene - by column chromatography (PN-90/A-75101/12);

$>$ Nitrates $(\mathrm{V})$ - by the colorimetric method with the use of salicylic acid.

The results were processed statistically by analysis of variance (ANOVA). The significance of differences between means was estimated by Tukey's range test at $\alpha=0.01$. All calculations were performed using STATISTICA 10 software.

\section{Results and Discussion}

A significant correlation was noted between the herbage yield and ecotype of basil. 'Minette' basil was characterized by the highest fresh herbage, dried herbage and crumbled herbage yields. 'Siam Queen' basil produced similar herbage yields. High dry herbage and crumbled herbage yields were also attained in sweet basil. Our results are comparable with those reported by Roslon et al. (2011) in whose study the fresh herbage yield of basil reached $1.04 \mathrm{~kg} \mathrm{~m}^{-2}$. Cinnamon basil and lemon basil were characterized by the lowest fresh herbage, dried herbage and crumbled herbage yields.

Previous research has shown that the herbage yield and quality of basil are significantly affected by fertilization. In a study by Nurzynska-Wierdak et al. (2011a), fresh herbage yield was significantly higher $\left(3.40 \mathrm{~kg} \mathrm{~m}^{-2}\right.$, two-year average) in basil plants grown in an unheated plastic tunnel and fertilized with nitrogen. In a pot experiment conducted by Biesiada and Kus (2010), the fresh herbage yield of basil ranged from 2.65 to $4.34 \mathrm{~kg}$ $\mathrm{m}^{-2}$ depending on fertilizer rate. In our study, a statistical analysis of two-year data demonstrated that Florovit had no significant effect on the fresh herbage, dried herbage or crumbled herbage yields of basil (Table 1). 
Table 1. The effect of ecotype and foliar fertilization with Florovit on basil yield $\left(\mathrm{kg} \mathrm{m}^{-2}\right)$

\begin{tabular}{|c|c|c|c|c|}
\hline \multirow{2}{*}{ Basil ecotype } & \multirow{2}{*}{ Fertilizer rate } & Fresh herbage yield & Dry herbage yield & Crumbled herbage yield \\
\hline & & \multicolumn{3}{|c|}{$\left(\mathrm{kg} \mathrm{m}^{-2}\right)$} \\
\hline \multirow{3}{*}{ Sweet basil } & I & 0.62 & 0.25 & 0.04 \\
\hline & II & 0.76 & 0.20 & 0.08 \\
\hline & III & 0.90 & 0.16 & 0.10 \\
\hline \multirow[t]{2}{*}{ Mean } & & 0.76 & 0.21 & 0.07 \\
\hline & I & 0.78 & 0.17 & 0.05 \\
\hline \multirow{2}{*}{ 'Siam Queen' basil } & II & 0.94 & 0.16 & 0.07 \\
\hline & III & 1.09 & 0.17 & 0.11 \\
\hline \multirow[t]{2}{*}{ Mean } & & 0.93 & 0.17 & 0.08 \\
\hline & I & 0.98 & 0.19 & 0.08 \\
\hline \multirow[t]{2}{*}{ 'Minette' basil } & II & 1.07 & 0.20 & 0.09 \\
\hline & III & 1.11 & 0.22 & 0.09 \\
\hline \multirow[t]{2}{*}{ Mean } & & 1.05 & 0.20 & 0.08 \\
\hline & I & 0.39 & 0.06 & 0.04 \\
\hline \multirow[t]{2}{*}{ Purple basil } & II & 0.51 & 0.09 & 0.08 \\
\hline & III & 0.64 & 0.15 & 0.08 \\
\hline \multirow[t]{2}{*}{ Mean } & & 0.51 & 0.10 & 0.07 \\
\hline & I & 0.22 & 0.05 & 0.03 \\
\hline \multirow[t]{2}{*}{ Cinnamon basil } & II & 0.33 & 0.04 & 0.02 \\
\hline & III & 0.32 & 0.04 & 0.02 \\
\hline \multirow[t]{2}{*}{ Mean } & & 0.29 & 0.04 & 0.02 \\
\hline & I & 0.26 & 0.10 & 0.02 \\
\hline \multirow[t]{2}{*}{ Lemon basil } & II & 0.22 & 0.04 & 0.03 \\
\hline & III & 0.20 & 0.06 & 0.03 \\
\hline \multirow[t]{2}{*}{ Mean } & & 0.23 & 0.07 & 0.03 \\
\hline & I & 0.54 & 0.14 & 0.04 \\
\hline \multirow[t]{2}{*}{ Mean for fertilizer rate } & II & 0.64 & 0.12 & 0.06 \\
\hline & III & 0.71 & 0.13 & 0.07 \\
\hline \multicolumn{5}{|l|}{$\mathrm{LSD} \alpha=0.01$} \\
\hline Basil ecotype & & 0.16 & 0.10 & 0.02 \\
\hline Fertilizer rate & & n.s. & n.s. & n.s. \\
\hline Interaction & & 0.2 & n.s. & 0.02 \\
\hline
\end{tabular}

Note. I - control; II $-0.5 \%$ fertilizer rate; III $-1.0 \%$ fertilizer rate.

An analysis of the interaction between the experimental factors revealed that 'Minette' basil fertilized with $1.0 \%$ Florovit solution produced the highest fresh herbage yield $\left(1.11 \mathrm{~kg} \mathrm{~m}^{-2}\right)$. Sweet basil grown in the control treatment was characterized by the highest dry herbage yield $\left(0.25 \mathrm{~kg} \mathrm{~m}^{-2}\right)$. Crumbled herbage yield was highest in 'Siam Queen' basil and sweet basil fertilized with $1.0 \%$ Florovit solution $\left(0.11\right.$ and $0.10 \mathrm{~kg} \mathrm{~m}^{-2}$, respectively).

Basil is a popular culinary herb widely used in the Mediterranean cuisine. This spice and medicinal plant is rich in biologically active substances that deliver health benefits (Nurzynska-Wierdak, 2012). In the present study, the dry matter content of fresh basil herbage was significantly affected by the ecotype (Table 2). Lemon basil and cinnamon basil had the highest dry matter content (19.30\% and 19.14\%, respectively). Purple basil and 'Minette' basil were least abundant in dry matter ( $11.63 \%$ and $13.72 \%$, respectively). Foliar fertilization had no significant effect on the dry matter content of basil herbage, which was significantly influenced by the interaction between 
the experimental factors. The highest dry matter content was noted in lemon basil grown in the control treatment and in cinnamon basil fertilized with $0.5 \%$ Florovit solution. The lowest dry matter content was observed in purple basil, regardless of treatment, and in 'Minette' basil from the control treatment. The highest dry matter content of basil herbage, noted in our study, is similar to the values reported by Dzida (2010b) for basil fertilized with calcium carbonate $(28.42 \%$ and $29.15 \%)$. In experiments carried out by Martyniak-Przybyszewska and Wojciechowski (2004), and Jadczak and Grzeszczuk (2008), the dry matter content of basil herbage reached $12.50 \%$ and $12.89 \%$, respectively. In the work of Nurzynska-Wierdak et al. (2011b), basil plants fertilized with various potassium and nitrogen rates had a dry matter content of $13.20 \%$.

Table 2. The effect of ecotype and foliar fertilization with Florovit on the content of dry matter and organic compounds in basil herbage

\begin{tabular}{|c|c|c|c|c|c|c|c|}
\hline \multirow{2}{*}{ Basil ecotype } & \multirow{2}{*}{ Fertilizer rate } & \multirow{2}{*}{$\begin{array}{l}\text { Dry matter } \\
(\%)\end{array}$} & \multirow{2}{*}{$\frac{\text { Total sugar }}{\text { (g } 100 \mathrm{~g}^{-1} \text { f.m.) }}$} & \multirow{2}{*}{$\frac{\text { Ascorbic acid }}{\left(\mathrm{mg} 100 \mathrm{~g}^{-1} \text { f.m. }\right)}$} & \multirow{2}{*}{$\begin{array}{l}\text { Organic acid } \\
\left(\mathrm{mg} 100 \mathrm{~g}^{-1} \text { f.m. }\right)\end{array}$} & \multirow{2}{*}{$\frac{\text { B-carotene }}{\left(\mu \mathrm{g} \cdot 100 \mathrm{~g}^{-1} \text { f.m. }\right)}$} & \multirow{2}{*}{$\begin{array}{l}\text { Nitrate }(\mathrm{V}) \\
\left(\mathrm{mg} \mathrm{NO}_{3} \cdot \mathrm{kg}^{-1} \text { f.m.) }\right.\end{array}$} \\
\hline & & & & & & & \\
\hline & I & 15.39 & 7.54 & 11.08 & 2.21 & 563 & 1127 \\
\hline \multirow[t]{2}{*}{ Sweet basil } & II & 15.93 & 7.20 & 12.04 & 2.14 & 537 & 1471 \\
\hline & III & 18.22 & 8.22 & 10.69 & 2.48 & 576 & 1098 \\
\hline \multirow[t]{2}{*}{ Mean } & & 16.51 & 7.65 & 11.27 & 2.28 & 559 & 1232 \\
\hline & I & 14.18 & 8.16 & 9.68 & 1.74 & 579 & 1320 \\
\hline \multirow[t]{2}{*}{ 'Siam Queen' basil } & II & 15.05 & 8.94 & 11.56 & 1.94 & 538 & 1089 \\
\hline & III & 15.27 & 11.56 & 10.16 & 2.28 & 537 & 1029 \\
\hline \multirow[t]{2}{*}{ Mean } & & 14.83 & 9.55 & 10.47 & 1.99 & 551 & 1146 \\
\hline & I & 12.80 & 6.60 & 9.90 & 1.88 & 768 & 1127 \\
\hline \multirow[t]{2}{*}{ 'Minette' basil } & II & 14.90 & 7.20 & 9.20 & 1.94 & 568 & 751 \\
\hline & III & 13.47 & 7.44 & 9.51 & 2.08 & 534 & 615 \\
\hline \multirow[t]{2}{*}{ Mean } & & 13.72 & 7.08 & 9.54 & 1.97 & 623 & 831 \\
\hline & I & 11.91 & 8.98 & 18.65 & 2.35 & 584 & 551 \\
\hline \multirow[t]{2}{*}{ Purple basil } & II & 10.99 & 6.48 & 17.84 & 1.68 & 553 & 633 \\
\hline & III & 11.99 & 7.98 & 18.09 & 1.94 & 505 & 695 \\
\hline \multirow[t]{2}{*}{ Mean } & & 11.63 & 7.81 & 18.19 & 1.99 & 547 & 627 \\
\hline & I & 19.36 & 6.00 & 10.81 & 2.41 & 593 & 1274 \\
\hline \multirow[t]{2}{*}{ Cinnamon basil } & II & 22.50 & 10.30 & 11.87 & 1.88 & 559 & 743 \\
\hline & III & 15.56 & 8.14 & 10.94 & 2.21 & 562 & 1137 \\
\hline \multirow[t]{2}{*}{ Mean } & & 19.14 & 8.15 & 11.21 & 2.17 & 571 & 1051 \\
\hline & I & 22.98 & 7.37 & 9.99 & 2.28 & 518 & 1904 \\
\hline \multirow[t]{2}{*}{ Lemon basil } & II & 15.87 & 9.75 & 17.44 & 2.08 & 364 & 1198 \\
\hline & III & 19.05 & 8.75 & 15.70 & 2.08 & 564 & 1319 \\
\hline \multirow[t]{2}{*}{ Mean } & & 19.30 & 8.62 & 14.38 & 2.14 & 482 & 1474 \\
\hline & I & 16.10 & 7.44 & 11.69 & 2.14 & 601 & 1217 \\
\hline \multirow[t]{2}{*}{ Mean for fertilizer rate } & II & 15.87 & 8.20 & 13.33 & 1.94 & 520 & 981 \\
\hline & III & 15.59 & 8.37 & 12.52 & 2.18 & 546 & 982 \\
\hline \multicolumn{8}{|l|}{$\mathrm{LSD} \alpha=0.01$} \\
\hline Basil ecotype & & 2.63 & 1.50 & 1.86 & n.s. & n.s. & 288 \\
\hline Fertilizer rate & & n.s. & n.s. & n.s. & 0.19 & n.s. & n.s. \\
\hline Interaction & & 2,21 & 0.22 & 0.32 & 0.22 & 221 & 219 \\
\hline
\end{tabular}

Note. I - control; II - 0.5\% fertilizer rate; III - $1.0 \%$ fertilizer rate. 
The concentrations of total sugars in basil herbage were affected by the ecotype and the ecotype $\mathrm{x}$ fertilizer interaction. Total sugar content was highest in 'Siam Queen' basil and lowest in 'Minette' basil. Florovit applied at a concentration of $1 \%$ contributed to the accumulation of total sugars in basil herbage $\left(11.56 \mathrm{~g}^{100 \mathrm{~g}^{-1}}\right.$ fresh weight). A higher total sugar content of basil herbage was reported by Nurzynska-Wierdak (2012).

L-ascorbic acid levels in basil herbage ranged from 9.68 to $18.65 \mathrm{mg}_{100 \mathrm{~g}^{-1}}$ fresh weight, and they were significantly affected by the ecotype and the ecotype $\mathrm{x}$ fertilizer interaction. Purple basil had the highest L-ascorbic acid content, at $18.19 \mathrm{mg} 100 \mathrm{~g}^{-1}$ fresh weight (mean of 2012-2013). Insignificantly higher concentrations of L-ascorbic acid (19.41 mg $100 \mathrm{~g}^{-1}$ fresh weight) were reported by Dzida (2011) for purple basil grown in pots.

A statistical analysis revealed that the organic acid content of basil herbage was significantly affected by foliar fertilization with Florovit and the fertilizer $\mathrm{x}$ ecotype interaction. The highest organic acid concentrations $(2.48 \mathrm{~g}$ $100 \mathrm{~g}^{-1}$ fresh weight on average) were noted in sweet basil fertilized with $1 \%$ Florovit solution, and the lowest in 'Siam Queen' basil (1.68 g $100 \mathrm{~g}^{-1}$ fresh weight). The effect of Florovit on the organic acid content of basil herbage was significant, but it varied across ecotypes depending on rate.

Herb plants are a rich source of antioxidant compounds, including carotenoids (Nurzynska-Wierdak, 2012, Kopsell et al., 2005). According to Daly et al. (2010), the average B-carotene content of basil herbage is 258 $\mu \mathrm{g} \cdot 100 \mathrm{~g}^{-1}$. In our study, $\beta$-carotene concentrations were highest in 'Minette' basil grown in the control treatment

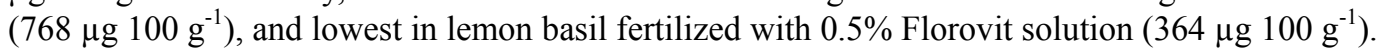

The nitrate $(\mathrm{V})$ content of herbage is an important consideration in the greenhouse production of herbs and spices. Nitrate accumulation in plant material can be prevented with the use of liquid organic fertilizers, which are particularly recommended for certified organic plantations (Wierzchowska-Renke i in. 1995). No maximum permissible nitrate $(\mathrm{V})$ levels have been established for herb and spice plants. The results of chemical analyses indicate that the herbage of control lemon basil plants had the highest nitrate(V) content $\left(1904 \mathrm{mg} \mathrm{NO} \mathrm{Ng}^{-1} \mathrm{fresh}\right.$ weight). Foliar fertilization did not increase nitrate concentrations, which reached an average of 981 and $982 \mathrm{mg}$ $\mathrm{NO}_{3} \cdot \mathrm{kg}^{-1}$ fresh weight in basil ecotypes fertilized with $0.5 \%$ and $1 \%$ Florovit solutions, respectively. In a study by Seidler-Łozykowska et al. (2007, 2009), nitrate(V) levels in organically-grown basil ranged from 306.2 to $5250.0 \mathrm{mg} \mathrm{NO}{ }_{3} \cdot \mathrm{kg}^{-1}$ fresh weight, depending on the region and cultivation method. According to Telesiński et al. (2013), the nitrate(V) content of basil herbage can be as high as $9950 \mathrm{mg} \mathrm{NO}{ }_{3} \cdot \mathrm{kg}^{-1}$ fresh weight.

\section{Conclusions}

Basil yield was significantly affected by the ecotype. 'Minette' and 'Siam Queen' basil was characterized by the highest fresh herbage yield.

Foliar fertilization with Florovit solution had no statistically significant effect on the herbage yield of greenhouse-grown basil.

The fresh herbage of 'Minette' basil contained the lowest concentrations of dry matter, total sugars, L-ascorbic acid, organic acids and nitrates $(\mathrm{V})$.

\section{Acknowledgements}

The study was financed as part of research project No. 1014.0804.

\section{References}

Aharoni, N., Dvir, O., Chalupowicz, D., \& Aharon, Z. (1993). Coping with postharvest physiology of fresh culinary herbs. Acta Hort, 344, 69-78.

Biesiada, A., \& Kus, A. (2010). The effect of nitrogen fertilization and irrigation on yielding and nutritional status of sweet basil (Ocimum basilicum L.). Acta Sci. Pol., Hortorum Cultus, 9(2), 3-12.

Daly, T., Jiwan, M. A., O'Brien, N. M., \& Aherne, S. A. (2010). Carotenoid content of commonly consumed herbs and assessment of their bioaccessibility using an in vitro digestion model. Plant Foods Human Nutr, 65, 164-169. http://dx.doi.org/10.1007/s11130-010-0167-3

Dzida, K. (2010a). Nutriens contents in sweet basil (Ocimum basilicum L.) herb depending on calcium carbonate dose and cultivar. Acta Sci. Pol., Hortorum Cultus, 9(4), 143-151.

Dzida, K. (2010b). Biological value and essential oil content in sweet basil (Ocimmum basilicum L.) depending on calcium fertilization and cultivar. Acta Sci. Pol., Hortorum Cultus, 9(4), 153-161.

Dzida, K. (2011). Influence of nitrogen nutrition and cultivar on quality of sweet basil herbs. Ann. UMCS, 24(3), 125-132. 
Kopsell, D. A., Kopsell, D. E., \& Curran-Celentano, J. (2005). Carotenoid and chlorophyll pigments in sweet basil grown in the field and greenhouse. HortSci., 40(5), 1230-1233.

Jadczak, D., \& Grzeszczuk, M. (2008). Zioła przyprawowe - wartość biologiczna wybranych gatunków. Panacea, 2(23), 15-17.

Jadczak, D., Błaszczuk, A., \& Rekowska, E. (2006). Effect of cocering on the of macroelements in field of Basil (Ocimum basilicum L.) cultivated for bunch harvest. J. Elementol., 11(2), 135-141.

Martyniak-Przybyszewska, B., \& Wojciechowski, T. (2004). Plonowanie wybranych gatunków roślin przyprawowych w rejonie Olsztyna. Folia Unic. Agric. Stetin., Agricultura, 239(95), 245.

Nurzynska-Wierdak, R. (2012). Ocimum basilicum L. - wartościowa roślina przyprawowa, lecznicza i olejkodajna. Ann. UMCS, 21(1), 20-30.

Nurzynska-Wierdak, R., \& Borowski, B. (2011). Dynamics of sweet basil (Ocimum basilicum L.) growth affected by cultivar and foliar feeding with nitrogen. Acta Sci. Pol., Hortorum Cultus, 10(3), 307-317.

Nurzynska-Wierdak, R., Borowski, B., \& Dzida, K. (2011a). Yield and chemical composition of basil herb depending on cultivar and foliar feeding with nitrogen. Acta Sci. Pol., Hortorum Cultus, 10(1), 207-219.

Nurzynska-Wierdak, R., Rożek, E., \& Borowski, B. (2011b). Response of different basil cultivars to nitrogen and potassium fertilization: total and mineral nitrogen content in herb. Acta Sci. Pol., Hortorum Cultus, 10(4), $217-232$

Nurzynska-Wierdak, R., Rożek, E., Dzida, K., \& Borowski, B. (2012). Growth response to nitrogen and potassium fertilization of common basil (Ocimum basilicum L.) plants. Acta Sci. Pol., Hortorum Cultus, 11(2), 275-288.

Roslon, W., Osinska, E., Baczek, K., \& Weglarz, Z. (2011). The influence of organic-mineral fertilizers on yield and raw materials quality of chosen plants of the Lamiaceae family from organic cultivation. Acta Sci. Pol., Hortorum Cultus, 10(1), 147-158.

Seidler-Łozykowska, K., Kozik, E., Golcz, A., \& Wójcik, J. (2007). Quality of basil herb (Ocimum basilicum L.) from organic and conventional cultivation. Herba Polonica, 53(3), 41-46.

Seidler-Łozykowska, K., Mordalski, R., Kucharski, W., Golcz, A., Kozik, E., \& Wojcik, J. (2009). Economic and qualitative value of the raw material of chosen species of medicinal plants from organic farming part ii. yield and quality of sweet basil herb (Ocimum basilicum L.). Acta Sci. Pol., Agricultura, 8(3), 29-35.

Telesiński, A., Grzeszczuk, M., Jadczak, D., Wysocka, G., \& Onyszko, M. (2013). Ocena zmian zawartości azotanów (V) w wybranych ziołach przyprawowych w zależności od sposobu ich utrwalania i czasu przechowywania. Żywność. Nauka. Technologia. Jakość., 5(90), 168-176.

Wierzchowska-Renke, K., Gajewska, R., \& Nabrzynski, M. (1995). Zawartość azotynów i azotanów w ziołach. Wiad. Zielar., 6, 13-14.

\section{Copyrights}

Copyright for this article is retained by the author(s), with first publication rights granted to the journal.

This is an open-access article distributed under the terms and conditions of the Creative Commons Attribution license (http://creativecommons.org/licenses/by/3.0/). 